\title{
An Empirical Investigation of Trade Liberalization and Trade Patterns in South Africa
}

\author{
Sibanisezwe Alwyn Khumalo1*, Asrat Tsegaye² \\ ${ }^{1}$ Rhodes University, Department of Economics and Economic History, South Africa \\ 2University of Fort Hare, Department of Economics East London, South Africa \\ alwyn.khumalo@gmail.com*, atsegaye@ufh.ac.za
}

\begin{abstract}
The study made use of the gravity model to analyze the behavior of South Africa's trade patterns at industry level. Using SIC 2-digit level data for the period 1996-2013 based on two sub-samples, 1996-2004 and 2005-2013, the study found that trade liberalization was not universally influential on trade patterns. Some industries did not exhibit significant behavior changes as a result of tariff liberalization. The results show that Agriculture, mining ores, crude oil, machinery and transport are the only industries from the selected sample of nine that are significantly influenced by trade liberalization policy. Furthermore, empirical results indicate that trade liberalization hinders extensive margins and does not encourage intensive margins.
\end{abstract}

Keywords: Gravity model, fixed effects, extensive margins, intensive margins, tariff liberalization.

\section{Introduction}

Poverty reduction, improved industry productivity and greater access to a bigger market are all expected benefits that Stigliz (2002) associates with the idea of linking economies and generating greater integration. Fiestas (2005) highlights that theory expects trade liberalization to stimulate long-run growth and to improve economic performance through strengthening the performance of industries. It is also vital to understand how the structure of trade patterns has been influenced in order to achieve these goals. Trade liberalization is viewed as a policy that can enhance productivity and innovation. The impact of spillover effects through opening up an economy is that domestic industries are then exposed to new innovation and better production methods. Increased competition is expected to boost local production and innovation, translating to improved domestic capacity and the ability to diversify both production and exports, as was highlighted by Adenikinju, and Chete (2002). Given this theoretical background it cannot be assumed that industries are homogeneous and thus are not expected to behave in the same manner under trade liberalization. By investing and understanding how each industry reacts under trade liberalization in relation to its ability to export and import, the paper seeks to add to the body of knowledge in order to better equip policy makers in their decision making. Both classical and new trade theories explain how trade patterns can be influenced within an economy. New trade theories, made popular by Krugman (1980) and Melitz (2003), developed a dynamic model of international trade, which has its foundations in the assumptions that firms within industries are not homogenous with respect to their total factor productivity, operate under monopolistic competition and offer differentiated products.

The paper based its investigation on this theoretical framework. Empirical evidence has generally looked at the influence of trade liberalization on growth in trade flows or the effect of productivity on extensive and intensive margins. Evidence in the case of South Africa shows, that imports generally increase (van der Westhuizen, 2006; Black 2001; Fedderke and Vaze, 2001). Moreover, empirical works on extensive and intensive margins demonstrate that higher demand elasticity increases the sensitivity of intensive margins while tariffs on a global scale have a greater impact on intensive rather than extensive margins (Buono and Lalanne, 2012). Chen (2013) noted that increased innovation is what drives growth in both intensive and extensive margins. Debaere and Mostashari (2010) find that on global scale tariffs can significantly influence extensive margins but that the effect is greatly reduced in relation to the global tariff's impact on trade flows. The lack of a consensus within empirical studies created a gap which the paper aimed to address with the goal of adding to the existing body of knowledge. The study thus seeks to understand how trade policy can influence trade patterns by looking at the role of trade liberalization policy and extensive and intensive margins have under the assumption of new trade theories. This is done by using the gravity model, which explains trade flows between South Africa and relevant trading partners, and how these could be influenced by trade liberalization measures. The empirical literature on South Africa has generally focused on the 
aggregate or single industry impact of trade liberalization on the magnitude of trade flows but not at how trade patterns may be influenced.

\section{Industry Trends for South Africa}

Applied weighted tariff averages are currently lower than the 1996 period, as may be observed in figure 1. Tariff averages have been declining over the years for most of the selected industries excepting textiles and wood. Textiles and Wood have shown the greatest resistance to declining tariffs, indicating increased concern over domestic industries that are not as competitive as foreign counterparts. Moreover, the view that these are labor-intensive industries indicates that the primary policy goal is to limit job loss. Food and agriculture are the most volatile as these exhibits the highest frequency in terms of fluctuations. Their trajectory is also not as steep, thus indicating a general resistance to tariff liberalization. Figure 1 further indicates that tariff levels are reducing at a faster rate for industries with lower product classifications than those that are more diverse. This study thus adds to the literature on trade liberalization by looking at the effect on a panel of selected industries, taking into account industry dynamics. The paper is organized as follows: section 2 examines trends in export and import flows at the industry level, section 3 covers methodology and section 4 provides a discussion regarding the analysis of the results. Section 5 provides concluding remarks and section 6 supplies recommendations based on the findings from the analysis of results.

\section{Figure 1: Industry-Level Tariffs}

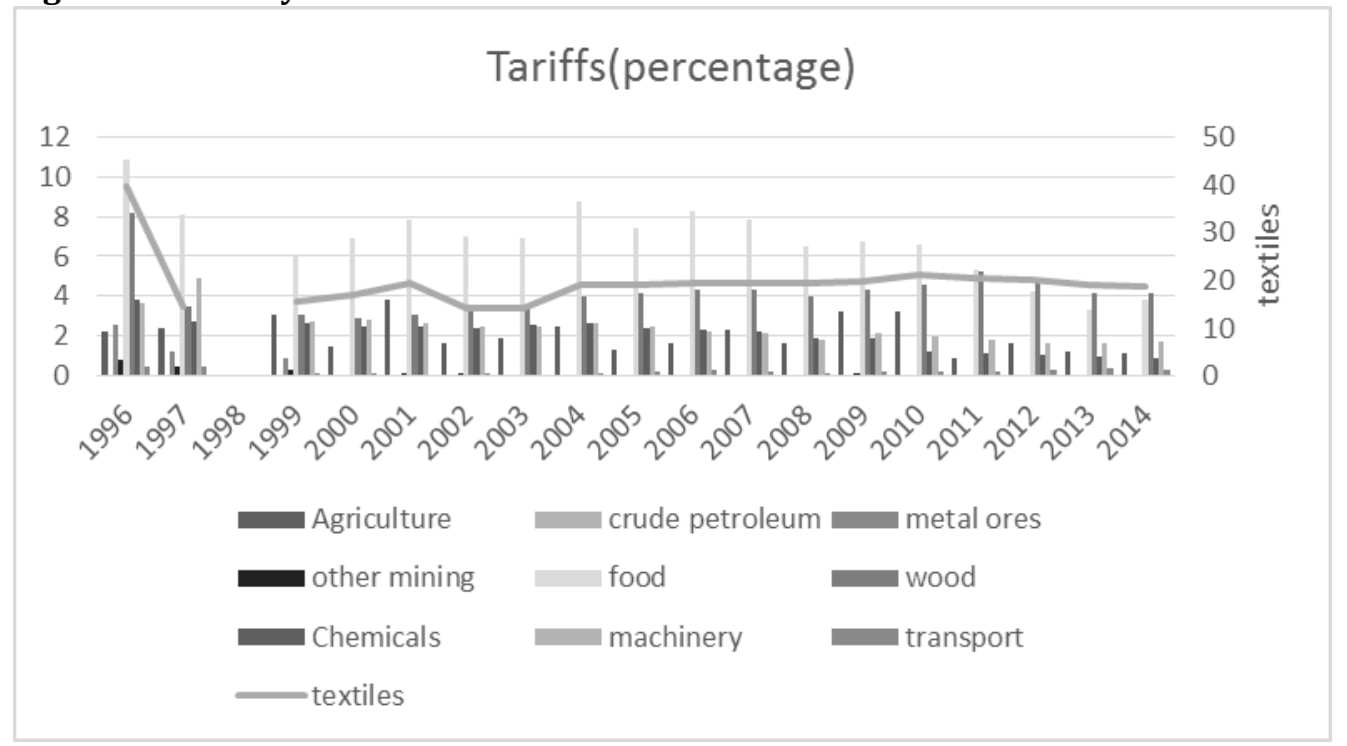

Source: adapted from Wits (2015)

In examining disaggregated values of exports in table 1(a) it is apparent that during the period of 1994-1999, growth in exports was driven by manufacturing, iron and steel, machinery and fuels. These are mainly capital-intensive industries. Trade liberalization policy appears to have had a greater positive impact on capital-intensive industries with respect to exports. This could be the effect of a buildup in inventory, as the increased engagement with the international market created an immediate market for their inventories. The period 2000-2008 shows a similar level in the growth rate of exports for all but fuel, mining and manufacturing, all of which showed resilience by maintaining high growth. Remaining industries, with the exception of textiles, have similar growth rates. The years 2009 and 2012 indicate that in all but one of the selected industries, values of exports declined. South Africa is not specializing in exports, but is diversifying the export base and working on improving exports in all sectors. The diversification of the export base is in line with policies the South African government has set to shift the focus of the economy to being outward orientated, in order to improve on extensive margins. In relation to manufacturing exports, SADC, EURO and NAFTA have been the major regional blocs that import South African manufactured products, as may be observed in figure 2 . The first nine years after independence were characterized by stagnant values of exports to regional blocs. The magnitude of fluctuations in demand for South African manufactured products was 
minimal. The period after 2003 saw growth in the value of South African manufactured products increase significantly, with the value of exports to EURO peaking at above US\$7 Billion in 2008 and to SADC peaking at close to US $\$ 10$ billion in 2011 . The period after 2008 was portrayed by a decline in exports to the EURO area and an increase in exports to NAFTA.

Table 1(a): Industry-Level Export Flows

\begin{tabular}{llllllll}
\hline Exports & Agriculture & Food & $\begin{array}{l}\text { Fuel and } \\
\text { mining }\end{array}$ & $\begin{array}{l}\text { Manufactu } \\
\text {-ring }\end{array}$ & $\begin{array}{l}\text { Iron } \\
\text { steel }\end{array}$ & $\begin{array}{l}\text { Machinery } \\
\text { and transport }\end{array}$ & Textiles \\
Year & & & & & & & \\
\hline 1994 & 2365.02 & & 2985.60 & 10841.34 & 2127.37 & 1866.18 & 164.33 \\
1995 & 2386.95 & & 4764.24 & 13496.94 & 2785.00 & 2478.00 & 238.00 \\
1996 & 2504.24 & & 5217.50 & 13296.41 & 2418.00 & 2636.00 & 255.00 \\
1997 & 2601.93 & & 5588.53 & 19993.27 & 2558.00 & 3321.00 & 273.00 \\
1998 & 2486.69 & & 4680.89 & 18428.73 & 2444.00 & 3334.00 & 230.00 \\
1999 & 2475.61 & & 4828.96 & 18933.20 & 2318.15 & 4056.33 & 235.48 \\
2000 & 3270.44 & 2232.01 & 5463.78 & 13997.13 & 2757.98 & 4569.98 & 237.37 \\
2001 & 3199.61 & 2344.65 & 8983.58 & 13732.76 & 2176.22 & 5226.50 & 230.74 \\
2002 & 3328.53 & 2448.94 & 5375.72 & 14131.44 & 2411.33 & 5257.28 & 246.24 \\
2003 & 4237.76 & 3126.68 & 9125.40 & 18048.46 & 3877.44 & 6544.18 & 298.45 \\
2004 & 4661.27 & 3510.23 & 12514.55 & 22703.52 & 5649.29 & 7937.49 & 301.16 \\
2005 & 5246.02 & 3990.25 & 15327.35 & 26073.50 & 5863.90 & 9574.11 & 311.60 \\
2006 & 4954.96 & 3734.15 & 19972.19 & 27343.01 & 5647.88 & 11293.34 & 302.32 \\
2007 & 5573.69 & 4213.90 & 25541.15 & 32469.06 & 7460.14 & 13411.65 & 332.26 \\
2008 & 7036.56 & 5428.72 & 28600.93 & 38098.02 & 8859.68 & 16229.15 & 300.77 \\
2009 & 6678.82 & 5466.60 & 21761.64 & 25216.24 & 5116.16 & 10786.59 & 225.60 \\
2010 & 9931.54 & 8230.26 & 32156.45 & 39773.25 & 7996.85 & 16296.16 & 415.20 \\
2011 & 11101.71 & 9012.22 & 41504.62 & 44204.45 & 7926.66 & 18970.10 & 447.50 \\
2012 & 10498.62 & 8742.28 & 36196.61 & 42741.20 & 6699.47 & 19088.34 & 426.33 \\
2013 & 11137.23 & 9293.84 & 36469.76 & 40244.65 & 6204.26 & 17873.22 & 424.22 \\
2014 & 11373.57 & 9455.05 & 31666.66 & 42292.46 & 6795.60 & 18692.52 & 407.31 \\
\hline
\end{tabular}

In comparison imports, as shown in table 1(b), have also been on the rise. All industries experienced an increase in imports except in the year 2009, whereupon all industries exhibited contractions. Additionally, it may be observed from table 1(b) that the growth rate of imports in selected industries increased from the year 2000. In as much as global demand for South African goods on average increased over these years, so did the demand for foreign goods by the domestic economy. South Africa as an emerging economy is exhibiting high levels of intra-industry trade. Observations from table 1(b) show that the goal of import substitution was not being achieved.

Table 1(b): Industry-Level Import Flows

\begin{tabular}{llllllll}
\hline Imports & Agriculture & Food & $\begin{array}{l}\text { Fuel and } \\
\text { mining }\end{array}$ & $\begin{array}{l}\text { Manufact- } \\
\text { uring }\end{array}$ & $\begin{array}{l}\text { Iron and } \\
\text { steel }\end{array}$ & $\begin{array}{l}\text { Machinery } \\
\text { and transport }\end{array}$ & Textiles \\
Year & & & & & & & \\
\hline 1994 & 1800.13 & 1339.24 & 405.70 & 17642.88 & 322.49 & 10223.92 & 651.06 \\
1995 & 2404.00 & 1787.00 & 2860.78 & 20810.00 & 415.00 & 12011.00 & 736.00 \\
1996 & 2261.00 & 1719.00 & 3168.62 & 20943.00 & 428.00 & 11945.00 & 675.00 \\
1997 & 2242.00 & 1713.00 & 4205.98 & 21002.00 & 355.00 & 12086.00 & 679.00 \\
1998 & 1804.00 & 1395.00 & 2842.28 & 19869.00 & 354.00 & 11835.00 & 597.00 \\
\hline
\end{tabular}




\begin{tabular}{|c|c|c|c|c|c|c|c|}
\hline \multicolumn{8}{|c|}{$\begin{array}{c}\text { Journal of Economics and Behavioral Studies (ISSN: 2220-6140) } \\
\text { Vol. 10, No. 5, pp. 125-137, October } 2018 \\
\end{array}$} \\
\hline 1999 & 1666.65 & 1306.17 & 3068.00 & 18788.00 & 322.83 & 10635.00 & 562.27 \\
\hline 2000 & 1650.29 & 1254.43 & 4536.00 & 18265.95 & 323.57 & 9839.32 & 569.38 \\
\hline 2001 & 1461.22 & 1114.57 & 4312.84 & 17664.55 & 316.20 & 9800.44 & 507.30 \\
\hline 2002 & 1686.99 & 1302.85 & 3918.09 & 18184.63 & 337.19 & 9826.94 & 532.72 \\
\hline 2003 & 2198.63 & 1716.42 & 5042.93 & 24055.54 & 451.96 & 13595.00 & 640.17 \\
\hline 2004 & 2968.07 & 2362.42 & 8193.80 & 32365.67 & 655.60 & 18829.87 & 817.79 \\
\hline 2005 & 3047.69 & 2450.93 & 9254.96 & 37919.89 & 828.44 & 21672.15 & 872.16 \\
\hline 2006 & 3649.23 & 2976.62 & 14732.63 & 44796.84 & 1130.89 & 25890.30 & 964.49 \\
\hline 2007 & 4888.29 & 4128.45 & 17479.28 & 51676.35 & 1572.56 & 29795.18 & 1015.42 \\
\hline 2008 & 5363.84 & 4588.64 & 22492.53 & 53893.31 & 1549.02 & 30670.04 & 1019.07 \\
\hline 2009 & 4730.48 & 4163.33 & 14850.53 & 40671.14 & 1029.63 & 22201.29 & 905.77 \\
\hline 2010 & 6295.77 & 5482.67 & 17681.80 & 53592.80 & 1344.91 & 29012.50 & 1164.86 \\
\hline 2011 & 8065.81 & 7008.69 & 23776.62 & 64735.98 & 1846.35 & 35680.43 & 1421.41 \\
\hline 2012 & 8398.51 & 7448.28 & 25218.07 & 64113.81 & 1707.39 & 35037.37 & 1377.21 \\
\hline 2013 & 7677.50 & 6777.07 & 24556.59 & 64932.72 & 2093.28 & 35438.24 & 1367.55 \\
\hline \multicolumn{8}{|l|}{2014} \\
\hline & 7148.34 & 6272.23 & 25495.47 & 60630.40 & 1598.15 & 32416.18 & 1343.54 \\
\hline
\end{tabular}

Source: WT0 (2015)

As shown in Table 1, manufacturing, machinery and equipment and textiles are the industries that consistently have negative net export values. This could be the result of excess domestic demand, consumer preferences or lack of competitiveness within these industries. This may also be an indication that local firms are not able to increase their production capacity. The lack of competitiveness in these industries highlights the high production costs that exist within the domestic economy relative to foreign firms. The high production costs hinder the expansion capabilities of the firms in these industries as this will result in firms experiencing decreasing returns to scale. One reason that can be applicable to the South African economy is the high cost of some of the factors of production required by these industries. Scarce factors of production will result in higher prices explaining the Samuelsson Stapler theory (Appleyard, Field and Cobb 2008: 136). Another consideration is product differentiation, which is subject to consumer preferences. The high imports within these industries can be attributed to choices made by the domestic market. On the other hand, the automotive industry has expressed fluctuations in terms of positive and negative net exports. The automotive industry experienced negative net exports during periods when the rand exchange rate depreciated. This indicates that foreign demand for automotive products is sensitive to the exchange rate, with the depreciation of the rand resulting in an increase in imports. The reason for this could be linked to the depreciation of the domestic currency (Rand) and reduced competitiveness from the EURO area.

\section{Methodology}

The gravity model is an adaptation of the gravity equation, an equation derived by Jan Tinbergen (Feenstra \& Taylor, 2014). The gravity equation is based on the principle of gravity. The gravity equation explains trade patterns that exist between trading partners. The model explains trade flows between trade partners, how these could influence the level of intensive margins in relation to trade partners and also, to some extent, extensive margins. The gravity equation is necessitated by the assumption of monopolistic competition in explaining international trade. The assumption of monopolistic competition is the foundation of the relevance of the gravity equation. The gravity equation is therefore able to explain trade patterns that also involve intraindustry trade. Anderson and Wincoop (2003, p170) note that the gravity model has received good reviews in its ability to provide a link between trade flows, economic and institutional variables. Furthermore, Kanda and Jordaan (2010) found that when analyzing bilateral effects of trade, the gravity model is applicable to expost analysis as compared to the Computable general equilibrium model, which is more applicable to ex-ante analysis. Furthermore, trade liberalization does not encourage intensive margins but is expected to hinder 
extensive margins. This lies in contrast to the views adopted by Melitz (2003), Debaere and Mostashari (2010) and Chen (2013).

Figure 2: South Africa's Manufactured Exports by Regional Destination

\section{manuafactured exports: US\$়(1000)}

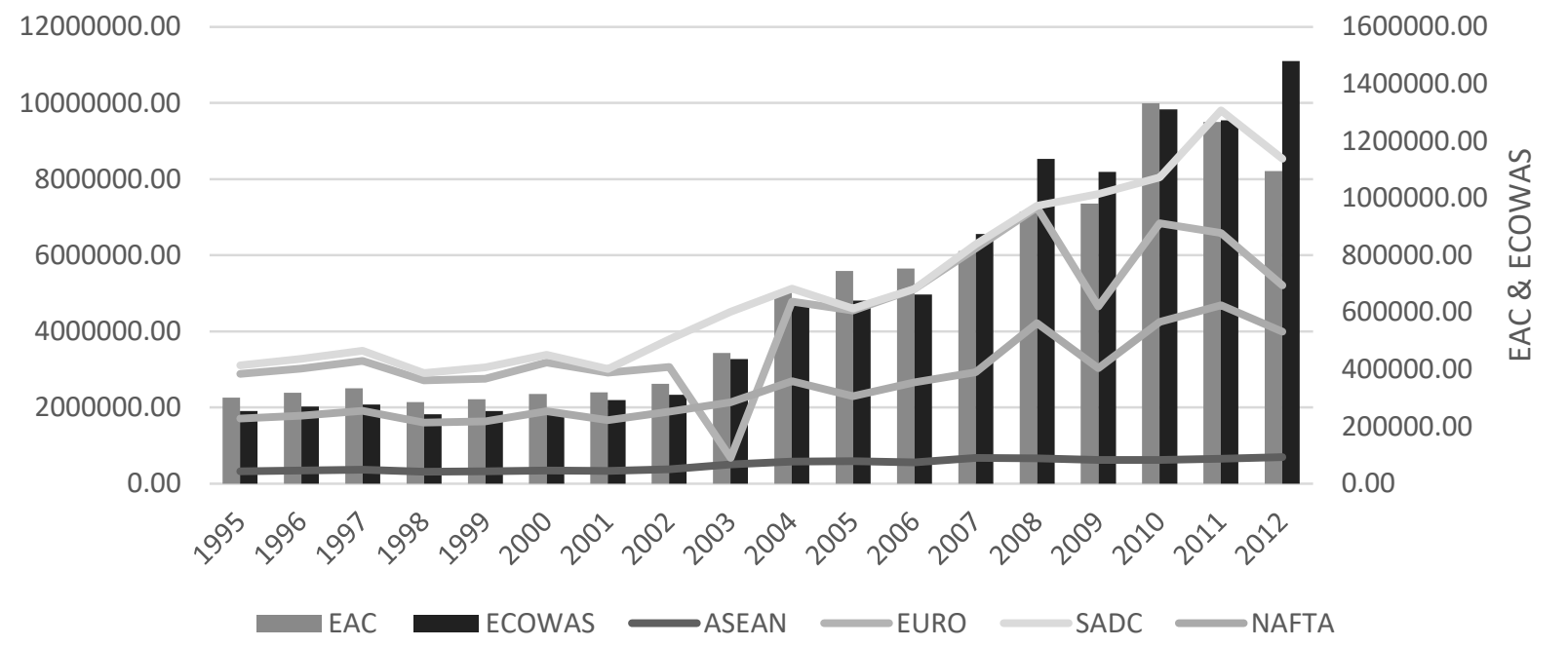

Source: UNCTAD 2014

A breakdown of exports shows that the EURO area is the prevalent destination for primary commodities and precious metals. The high demand by EURO is driven by specialization as a result of comparative advantage. The EURO area has a comparative disadvantage in the production of primary commodities and precious minerals. In relation to the EURO area, South Africa has a comparative advantage in the production of primary and precious materials. The comparative advantage is driven by the different factor endowments between the two trading partners. South Africa is labor-intensive whilst the EURO area is capital-intensive.

Figure 3: South Africa's Primary Exports by Regional Destination

EXPORT:Primary commodities, precious metals and nonmonetary gold (US\$1000s)

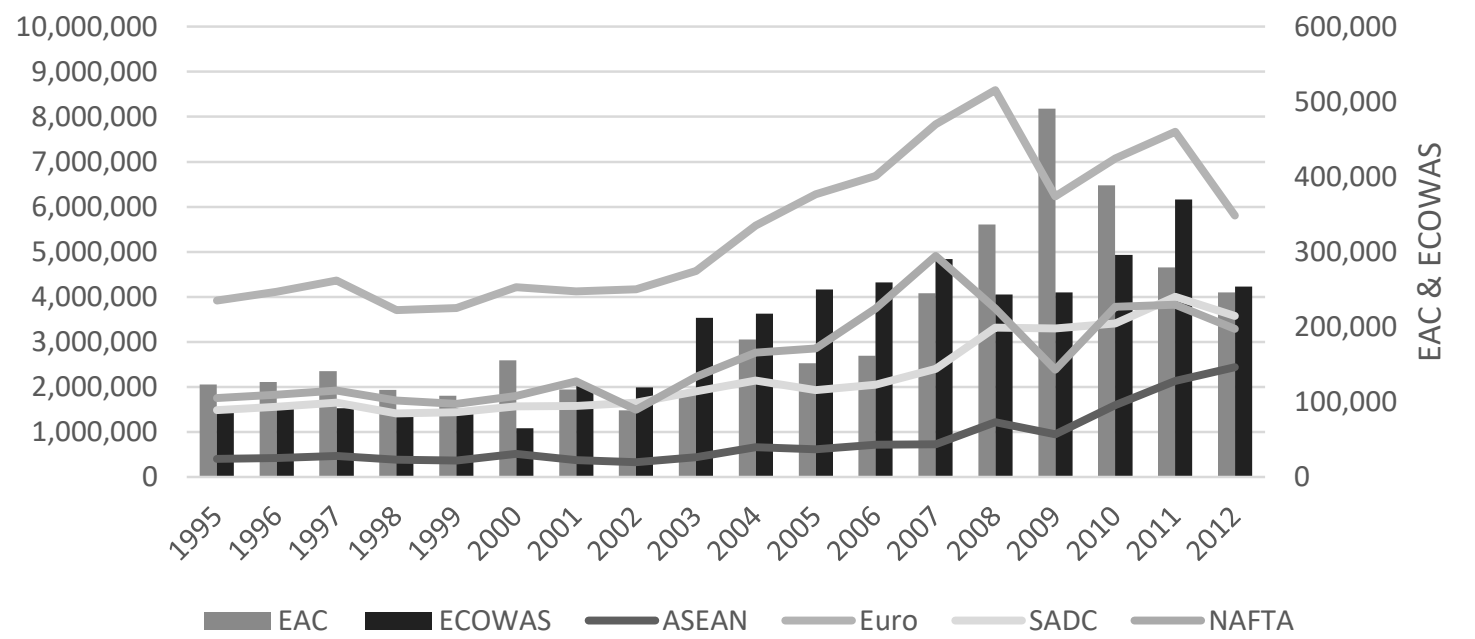

Source: UNCTAD 2014 
NAFTA and SADC are behind the EURO area with regards to the acquisition of South African exports of primary commodities and precious metals. The demand for primary products from SADC has increased over the years and resulted in it being second after the EURO area in 2011 and 2012. This can be attributed to the strengthening of the SADC bloc by converting it into a free trade area and South Africa, being the dominant player, has benefitted greatly from the regional bloc. In relation to SADC economies, South Africa has an absolute advantage in terms of resources and factors of production. With the majority of countries in the region being classified as low income, but on the other hand a significant number of countries in SADC are resource rich in nature. According to Twerefou (2009:1) over half the world's reserves in minerals, such as diamonds and gold, are found in South Africa. The growth of South African exports to SADC could be a factor of the infancy stage of development of the other member states within SADC, which may not be in line with traditional trade theories.

\section{The Gravity Model May be Expressed as Follows:}

$\log \left(\right.$ bilateral trade $\left.e_{i j}\right)=\alpha+\beta \log ($ demo $)+\beta$ (demod $)+\gamma \log$ (Trade factors $)+\gamma$ (trade factorsd $) \ldots .1$

Where demo represents a vector of demographic factors between trading partners expressed as nominal values, Trade factors represents a vector of factors that affect international trade expressed as nominal values, while demo and trade factors represent the variables expressed as dummy variables. The variables expressed in their nominal values will be logged. The augmented model is expressed as follows:

$\log \mathrm{T}_{\mathrm{ij}}=\beta_{\mathrm{o}}+\beta_{1} \log \left(\right.$ inc $\left._{\mathrm{i}} \operatorname{Inc}_{\mathrm{j}}\right)+\beta_{2} \log \left(\right.$ Pop $_{\mathrm{i}}$ pop $\left._{\mathrm{j}}\right)+\beta_{3} \log \operatorname{dis}_{\mathrm{ij}}+\beta_{4} \operatorname{devl}_{\mathrm{ij}}+\beta_{5}$ bord $_{\mathrm{ij}}+\beta_{6} \operatorname{Intgr}_{\mathrm{ij}}+$ $\beta_{7}$ ECOWAS $_{j}+\beta_{8}$ EAC $_{j}+\beta_{9}$ NAFTA $_{j}+\beta_{10}$ EU $_{j}+\beta_{11} \log \operatorname{exch}_{i j}+\beta_{12} \operatorname{tarf}_{t}+\beta_{13}$ dtar $_{t}+\mu_{i j} \quad \ldots . .2$

Using Standard Industry Classification 2-digit data from the World Bank's data bank for the period 19962013, the two subsamples were analyzed using a semi-log model and log-linear model.

\section{Results and Discussion}

Results obtained from the gravity model indicate that trade flows for some of the selected industries will be influenced by trade liberalization. These industries are Agriculture, crude oil and natural gas, mining ores, machinery and transport equipment. Policy changes to tariff levels will influence the flow of trade, be it exports of imports, and thus influence trade patterns of South Africa and relevant industry partners.

Table 2: Results of the Agriculture Industry

\begin{tabular}{|c|c|c|c|c|c|c|c|c|}
\hline \multirow[t]{2}{*}{ sample } & \multicolumn{2}{|c|}{ Imports 1996-2004 } & \multicolumn{2}{|c|}{ Imports 2005-2013 } & \multicolumn{2}{|c|}{ Exports 1996-2004 } & \multicolumn{2}{|c|}{ Exports 2005-2013 } \\
\hline & $\begin{array}{l}\text { Model } \\
1^{1}\end{array}$ & $\begin{array}{l}\text { Model } \\
2^{2}\end{array}$ & Model 1 & Model 2 & Model 1 & Model 2 & Model 1 & Model 2 \\
\hline Log income & 0.006 & -0.346 & $0.034 *$ & 1.097 & $0.081^{* * *}$ & 0.02 & $-.0285^{* *}$ & -0.266 \\
\hline $\begin{array}{l}\text { Log } \\
\text { population }\end{array}$ & 0.017 & -0.712 & -0.022 & -3.773 & $-0.382^{* * *}$ & -1.312 & $0.1485^{* *}$ & 1.364 \\
\hline $\begin{array}{l}\text { Log distance } \\
\text { development }\end{array}$ & -0.186 & 1.054 & $\begin{array}{l}-0.138 \\
0.069^{*}\end{array}$ & $\begin{array}{l}-2.096 \\
11.463\end{array}$ & $\begin{array}{l}0.672^{* * *} \\
0.044\end{array}$ & $\begin{array}{l}2.027 \\
-4.066^{* * *}\end{array}$ & $\begin{array}{l}-0.212^{* *} \\
-0.377^{* *}\end{array}$ & $\begin{array}{l}-3.032 \\
-4.418^{* * *}\end{array}$ \\
\hline $\begin{array}{l}\text { Border } \\
\text { dummy }\end{array}$ & $\begin{array}{l}- \\
0.279^{* * *}\end{array}$ & -0.882 & -0.124 & $-12.89 * * *$ & $0.388^{* * *}$ & & -0.044 & 2.074 \\
\hline $\begin{array}{l}\text { Integration } \\
\text { dummy }\end{array}$ & -0.017 & 0.233 & -0.052 & $-9.238^{* *}$ & $-0.039^{*}$ & -0.41 & $0.118^{*}$ & -1.047 \\
\hline ECOWAS & $0.308^{*}$ & 0.011 & -0.066 & $\begin{array}{l}- \\
10.361^{* * *}\end{array}$ & -0.012 & $-2.38^{* * *}$ & 0.041 & $-1.421^{*}$ \\
\hline $\begin{array}{l}\text { EAC } \\
\text { Nafta }\end{array}$ & 0.026 & 0.284 & $\begin{array}{l}0.024 \\
0.024\end{array}$ & $\begin{array}{l}1.926 \\
5.415^{*}\end{array}$ & $\begin{array}{l}-0.0617^{*} \\
-0.831^{* * *}\end{array}$ & $\begin{array}{l}-0.67 \\
-6.69\end{array}$ & $\begin{array}{l}-0.064^{*} \\
-0.088^{*}\end{array}$ & $\begin{array}{l}0.712 \\
-1.886\end{array}$ \\
\hline EU & -0.062 & -3.266 & 0.035 & -5.45 & $-0.834^{* * *}$ & -6.415 & 0.227 & 1.347 \\
\hline $\begin{array}{l}\text { Exchange } \\
\text { rate }\end{array}$ & -0.001 & -0.014 & 0.0005 & 0.03 & $-0.002^{* * *}$ & -0.02 & 0.0001 & 0.0001 \\
\hline
\end{tabular}

\footnotetext{
${ }^{1}$ Semi- log model
}

2 Double log model 
Journal of Economics and Behavioral Studies (ISSN: 2220-6140)

Vol. 10, No. 5, pp. 125-137, October 2018

\begin{tabular}{|c|c|c|c|c|c|c|c|c|}
\hline tariff & -0.015 & -0.345 & -0.003 & -0.122 & 0.006 & -0.183 & 0.001 & -0.028 \\
\hline Tariff & -0.017 & $-0.733^{*}$ & $-0.019 * *$ & -0.527 & -0.0004 & $-0.801^{*}$ & 0.0008 & -0.074 \\
\hline \multicolumn{9}{|l|}{$\begin{array}{l}\text { liberalis } \\
\text { dummy }\end{array}$} \\
\hline $\begin{array}{l}\text { Interaction } \\
\text { dummy }\end{array}$ & $-1.3 e-11$ & $8.0 \mathrm{e}-10$ & $\begin{array}{l}5.5 \mathrm{e}- \\
11^{* *}\end{array}$ & $\begin{array}{l}2.5 \mathrm{e}- \\
09^{* * *}\end{array}$ & $3.3 e-11$ & $9.2 \mathrm{e}-10$ & $\begin{array}{l}1.6 \mathrm{e}- \\
11^{* *}\end{array}$ & $2.9 \mathrm{e}-10^{*}$ \\
\hline constant & 1.01 & 33.66 & 0.174 & 85.112 & $4.225^{* * *}$ & 32.823 & $-1.802^{*}$ & -9.311 \\
\hline Country 2 & $-0.233^{*}$ & $\begin{array}{l}- \\
9.662^{* * *}\end{array}$ & $-0.103^{* *}$ & $\begin{array}{l}- \\
12.472^{* * *}\end{array}$ & $-0.173^{* *}$ & & $0.093^{* * *}$ & $2.058^{* * *}$ \\
\hline Country 3 & & & $-0.135^{*}$ & & $-0.582^{* * *}$ & & $0.133^{*}$ & \\
\hline Country 4 & & & & & $-0.377^{* * *}$ & & $0.144^{*}$ & \\
\hline Country 5 & & & & & $-0.567^{* * *}$ & & $0.327^{* *}$ & \\
\hline Country 7 & & & & & $-0.672^{* * *}$ & & $0.301^{* *}$ & $4.536^{*}$ \\
\hline Country 8 & & & & & $0.344^{* * *}$ & $4.03^{*}$ & & \\
\hline Country 9 & $0.439 * * *$ & & $0.866^{* * *}$ & & & & $0.075^{*}$ & \\
\hline Country 10 & & & & & & & $-0.327^{*}$ & $-0.796^{*}$ \\
\hline Country 11 & & & & & $-1.379 * * *$ & & $0.630^{* *}$ & \\
\hline Country 12 & & & & & & & $-0.372^{* *}$ & $-1.88^{* * *}$ \\
\hline Country 13 & $-0.4^{* * *}$ & $-2.838^{* *}$ & & & $-0.574^{* * *}$ & & $0.238^{* *}$ & \\
\hline Country 14 & & & & & $0.277^{* * *}$ & & $-0.11^{* *}$ & -1.799* \\
\hline Country 15 & & & & & & & & -0.899* \\
\hline Country 16 & & $-4.485^{* *}$ & & & $-1.013^{* * *}$ & & $-0.335^{*}$ & \\
\hline Country 17 & $-0.119^{*}$ & & & $-8.62^{*}$ & & & $0.241^{* *}$ & \\
\hline Country 19 & & & $0.205^{* * *}$ & & & & & \\
\hline Country 20 & & & & & $-0.886^{* * *}$ & & $0.352^{* *}$ & \\
\hline Country 21 & & & & $11.268^{*}$ & & & $-0.09 *$ & \\
\hline Country 22 & & & & & $-0.929 * * *$ & & $0.242^{* *}$ & \\
\hline Country 23 & $-0.491^{*}$ & & & & & & & \\
\hline \multirow[t]{2}{*}{ Country 24} & & - & & & & & $0.708^{* * *}$ & $5.471^{*}$ \\
\hline & & $5.903^{* * *}$ & & & & & & \\
\hline Country 25 & & & & $15^{*}$ & $-0.099 * *$ & & $-0.320^{* *}$ & $-1.075^{* *}$ \\
\hline Country 26 & & & $-0.138^{*}$ & $-2.597^{*}$ & $-0.539^{* * *}$ & & $0.148^{* *}$ & \\
\hline Country 27 & & & & & $0.084^{* *}$ & & & \\
\hline Country 28 & & & & $14.516^{*}$ & $-0.1^{* *}$ & & $-0.275^{*}$ & \\
\hline Country 30 & & & & $-2.614^{*}$ & & & & \\
\hline Country 31 & $0.194^{* *}$ & & & $10.395^{*}$ & $-0.13^{* * *}$ & & & \\
\hline $\mathrm{N}$ & 181 & 181 & 277 & 254 & 210 & 189 & 277 & 255 \\
\hline R2 & 0.89 & 0.87 & 0.94 & 0.76 & 0.732 & 0639 & 0.889 & 0.737 \\
\hline $\mathrm{F}$ & 35.198 & 28.428 & 97.259 & 18.828 & 12.697 & 8.024 & 53.563 & 16.926 \\
\hline Prob $>F$ & 0.00 & 0.00 & 0.00 & 0.00 & 0.00 & 0.00 & 0.00 & 0.00 \\
\hline${ }^{*} \mathrm{p}<0.05$ & & & ${ }^{* *} \mathrm{p}<0.01$ & & & $* * * \mathrm{P}<0.001$ & & \\
\hline
\end{tabular}

Results obtained show that for agriculture, trade liberalization lowers the responsiveness of both exports and imports to changes in the determinants of trade flows. The movement towards lower elasticity levels limits the impact of the efforts of economic policy. In addition, the effects of trade liberalization lower the ratio of agriculture trade flows in relation to the total bilateral trade of trading partners. What has also been observed, is that under trade liberalization the number of significant trading partners is lower than when trade liberalization is not significant, indicating a reduction in extensive margins. 


\begin{tabular}{l} 
Journal of Economics and Behavioral Studies (ISSN: 2220-6140) \\
Vol. 10, No. 5, pp. 125-137, October 2018 \\
\hline \hline
\end{tabular}

Table 3: Results of the Crude Oil and Natural Gas Industry

\begin{tabular}{|c|c|c|c|c|c|c|c|c|}
\hline \multirow[t]{2}{*}{ sample } & \multicolumn{2}{|c|}{ Imports 1996-2004 } & \multicolumn{2}{|c|}{ Imports 2005-2013 } & \multirow{2}{*}{$\begin{array}{l}\text { Exports } \\
2004 \\
\text { Model } \\
1 \\
\end{array}$} & \multirow{2}{*}{$\begin{array}{l}\text { 1996- } \\
\text { Model } \\
2 \\
\end{array}$} & \multirow{2}{*}{$\begin{array}{l}\text { Exports } \\
2013 \\
\text { Model } \\
1\end{array}$} & \multirow{2}{*}{$\begin{array}{l}2005 \\
\text { Model } \\
2\end{array}$} \\
\hline & Model 1 & Model 2 & Model 1 & Model 2 & & & & \\
\hline Log income & 0.027 & -1.9 & -0.0824 & 0.1 & -0.009 & -0.702 & -0.006 & $-1.577^{*}$ \\
\hline $\begin{array}{l}\text { Log } \\
\text { population }\end{array}$ & 0.123 & 10.216 & $0.654^{*}$ & 1.405 & 0.042 & 4.593 & -0.036 & 3.894 \\
\hline Log distance & -1.1289 & -3.757 & $-0.837^{*}$ & -1.88 & -0.485 & -11.375 & 0.053 & -4.482 \\
\hline development & -0.353 & & $0.363^{* * *}$ & -6.5 & -0.171 & & -0.029 & -8.319 \\
\hline $\begin{array}{l}\text { Border } \\
\text { dummy }\end{array}$ & -2.617 & -0.786 & 1.04 & & -1.361 & & -0.121 & 2.206 \\
\hline $\begin{array}{l}\text { Integration } \\
\text { dummy }\end{array}$ & -0.017 & 0.677 & $0.836^{*}$ & 4.939 & -0.003 & -0.432 & -0.039 & 2.092 \\
\hline ECOWAS & -0.335 & 5.065 & $1.353^{* * *}$ & 3.251 & $-0.307^{*}$ & 9.439 & 0.0001 & 6.086 \\
\hline EAC & -0.085 & -2.36 & 0.059 & $4.903^{*}$ & $-0.072^{*}$ & -0.859 & -0.006 & 2.967 \\
\hline Nafta & & & $1.597^{* *}$ & 0.551 & & 13.941 & -0.109 & -0.272 \\
\hline EU & 0.058 & $4.836^{* *}$ & $1.243^{* *}$ & 8.306 & -0.095 & 8.318 & -0.108 & 1.805 \\
\hline Exchange rate & 0.00004 & 0.072 & -0.0006 & -0.01 & 0.0004 & 0.018 & 0.0002 & 0.037 \\
\hline tariff & & & -0.386 & 28.245 & & & 0.309 & 45.767 \\
\hline $\begin{array}{l}\text { Tariff liberalis } \\
\text { dummy }\end{array}$ & & & -0.02 & $1.09 *$ & & & -0.002 & 1.089 \\
\hline $\begin{array}{l}\text { Interaction } \\
\text { dummy }\end{array}$ & & & $7.0 \mathrm{e}-12$ & $-4.2 \mathrm{e}-11$ & & & $\begin{array}{l}3.0 \mathrm{e}- \\
11^{* * *}\end{array}$ & $3.2 \mathrm{e}-10$ \\
\hline constant & 4.758 & & $-13.179 *$ & -43.95 & 3.551 & -44.195 & 1.220 & -24.042 \\
\hline Country 2 & & $11.595^{* *}$ & $1.231^{* * *}$ & $7.207^{* *}$ & & & & 4.986 \\
\hline Country 4 & & $-8.943^{* *}$ & $0.759 *$ & & $-0.151^{*}$ & & & \\
\hline Country 5 & & & $1.438^{*}$ & & & & & \\
\hline Country 9 & & & $0.549 *$ & & & & & \\
\hline Country 11 & & & $3.359 *$ & & & & & \\
\hline Country 13 & & & & $9.719 * * *$ & & & & \\
\hline Country 14 & & & & $6.758^{*}$ & & & & \\
\hline Country 16 & & & $2.016^{*}$ & & & & & \\
\hline Country 17 & & $6.176^{*}$ & & & & & & \\
\hline Country 19 & & & & & & & $-0.063^{*}$ & \\
\hline Country 20 & & & $1.77^{*}$ & & & & & \\
\hline Country 21 & & & & & & & & \\
\hline Country 23 & & & & & & & & \\
\hline Country 24 & & & $1.472^{*}$ & & & & & \\
\hline Country 25 & & & & & & & & \\
\hline Country 26 & & & & & & & & \\
\hline Country 28 & & & & & & & & \\
\hline Country 30 & & & & & & & & $2.967^{*}$ \\
\hline Country 31 & & & $-1.303^{*}$ & $-5.835^{*}$ & & & & \\
\hline $\mathrm{N}$ & 248 & 137 & 277 & 194 & 248 & 204 & 277 & 246 \\
\hline $\mathrm{R} 2$ & 0.644 & 0.702 & 0.703 & 0.765 & 0.671 & 0.668 & 0.362 & 0.693 \\
\hline $\mathrm{F}$ & 10.956 & 9.507 & 15.775 & 14.681 & 12.331 & 11.15 & 3.786 & 13.1 \\
\hline Prob $>F$ & 0.00 & 0.00 & 0.00 & 0.00 & 0.00 & 0.00 & 0.00 & 0.00 \\
\hline$* \mathrm{p}<0.05$ & & & $* * \mathrm{p}<0.01$ & & & $* * * \mathrm{P}<0.0$ & & \\
\hline
\end{tabular}

Results from the crude oil and natural gas industry show that trade liberalization improved the level of elasticity of imports in the sub-sample 2005-2013. This made trade flows more sensitive to changes in the determinants, therefore aiding the impact of policy instruments in trying to support industry development both domestically and internationally. The trade liberalization variable does not influence the number of 
significant trading partners but resulted in a change in the significant trading partners. In this case, trade liberalization does not aid-intensive margins but encourages a shift in trading partners.

Table 4: Results of Mining Ores Industry

\begin{tabular}{|c|c|c|c|c|c|c|c|c|}
\hline \multirow[t]{2}{*}{ sample } & \multicolumn{2}{|c|}{ Imports 1996-2004 } & \multicolumn{2}{|c|}{ Imports 2005-2013 } & \multicolumn{2}{|c|}{ Exports 1996-2004 } & \multicolumn{2}{|c|}{ Exports 2005-2013 } \\
\hline & $\begin{array}{l}\text { Model } \\
1\end{array}$ & Model 2 & Model 1 & Model 2 & Model 1 & $\begin{array}{l}\text { Model } \\
2\end{array}$ & $\begin{array}{l}\text { Model } \\
1\end{array}$ & Model 2 \\
\hline Log income & 0.0006 & 2.866 & 0.041 & 0.353 & $-0.062^{* * *}$ & 1.812 & 0.005 & $5.291^{*}$ \\
\hline $\begin{array}{l}\text { Log } \\
\text { population }\end{array}$ & 0.008 & -29.469 & -0.215 & -13.164 & $0.537^{* * *}$ & -21.549 & -0.025 & $-24.929 *$ \\
\hline Log distance & -0.024 & & 0.278 & 5.072 & $-2.913^{* * *}$ & 18.65 & 0.032 & 1.771 \\
\hline development & -0.016 & & 0.541 & & $-1.711^{* * *}$ & & 0.064 & \\
\hline $\begin{array}{l}\text { Border } \\
\text { dummy }\end{array}$ & -0.013 & 70.14 & 0.036 & -2.351 & $-6.361^{* * *}$ & 8.289 & 0.018 & $-54.702^{*}$ \\
\hline $\begin{array}{l}\text { Integration } \\
\text { dummy }\end{array}$ & $\begin{array}{l}- \\
0.00004\end{array}$ & 0.013 & -0.212 & 8.781 & $0.038^{* *}$ & -2.289 & -0.025 & $-18.449 * *$ \\
\hline ECOWAS & 0.028 & 87.187 & -0.082 & & $-1.631^{* * *}$ & -9.246 & -0.0096 & $-16.921^{* *}$ \\
\hline EAC & -0.004 & 96.979 & $0.16^{*}$ & 11.046 & -0.005 & & 0.012 & \\
\hline Nafta & & 141.38 & 0.13 & 32.015 & $-0.211^{* * *}$ & 17.235 & 0.014 & 11.058 \\
\hline EU & 0.023 & 100 & -0.3 & & $0.477^{* * *}$ & & -0.035 & \\
\hline $\begin{array}{l}\text { Exchange } \\
\text { rate }\end{array}$ & -0.0001 & $-0.17^{*}$ & $-0.002^{* *}$ & $-0.233^{* *}$ & $0.0013^{* *}$ & -0.034 & 0.00003 & -0.023 \\
\hline tariff & 0.002 & -0.269 & & & $0.045^{* * *}$ & -1.587 & & \\
\hline $\begin{array}{l}\text { Tariff } \\
\text { liberalis } \\
\text { dummy }\end{array}$ & 0.001 & -1.02 & & & $0.025^{* *}$ & -0.779 & & \\
\hline $\begin{array}{l}\text { Interaction } \\
\text { dummy }\end{array}$ & $1.2 \mathrm{e}-09$ & $2.8 \mathrm{e}-06$ & & & $5.5 \mathrm{e}-11$ & $5.2 \mathrm{e}-09$ & & \\
\hline constant & -0.106 & 796.48263 & 3.065 & 399.70293 & $11.506^{* * *}$ & 495.229 & 0.331 & $588.73^{*}$ \\
\hline Country 2 & & & & & $-2.414^{* * *}$ & & & \\
\hline Country 3 & & & & & $1.466^{* * *}$ & & & \\
\hline Country 4 & & & & & $-0.384^{* * *}$ & & & \\
\hline Country 5 & & & & $11.19^{*}$ & $-0.941^{* * *}$ & & & \\
\hline Country 6 & & & & & & & & $55.659 *$ \\
\hline Country 7 & & & & & $1.256^{* * *}$ & & & \\
\hline Country 8 & & & & & $-0.789^{* * *}$ & & & \\
\hline Country 9 & & & & & $-1.571^{* * *}$ & & & \\
\hline Country 10 & & & & & $-1.454^{* * *}$ & & & \\
\hline Country 11 & & & & & & & & \\
\hline Country 12 & & & & & $-1.475^{* * *}$ & & $0.119 *$ & $15.759 * * *$ \\
\hline Country 13 & & & & $11.553^{*}$ & $1.004^{* * *}$ & & & \\
\hline Country 14 & & & & & -1.155 & & & 69.688* \\
\hline Country 15 & & & & & $-1.646^{* * *}$ & & & \\
\hline Country 16 & & & & & & & & \\
\hline Country 17 & & & $-0.3567^{*}$ & & $-2.027^{* * *}$ & & & \\
\hline Country 19 & & & & & $-3.325^{* * *}$ & & & \\
\hline Country 20 & & & & & $0.603^{* * *}$ & & & \\
\hline Country 21 & & $21.708^{*}$ & & & $1.78^{* * *}$ & & & $65.023^{*}$ \\
\hline Country 22 & & & & & & & & 9.15* \\
\hline Country 23 & & & & & $3.177^{* * *}$ & & & \\
\hline Country 24 & & & & & $0.7008^{* * *}$ & & & $14.166^{* *}$ \\
\hline Country 25 & & & & & $-1.453^{* * *}$ & & & \\
\hline Country 26 & & & & & $1.107^{* * *}$ & & & \\
\hline Country 27 & & & & & $-2.6^{* * *}$ & & & \\
\hline
\end{tabular}




\begin{tabular}{|c|c|c|c|c|c|c|c|c|}
\hline Country 28 & & & & & \multicolumn{3}{|c|}{$-1.194^{* * *}$} & $8.914^{* *}$ \\
\hline \multicolumn{5}{|l|}{ Country 30} & \multicolumn{3}{|c|}{$-3.481^{* * *}$} & $-9.443^{* *}$ \\
\hline \multicolumn{3}{|l|}{ Country 31} & \multicolumn{2}{|c|}{$0.1674^{* *}$} & \multicolumn{3}{|c|}{$1.941^{* * *}$} & 51.489* \\
\hline $\mathrm{N}$ & 247 & 52 & 277 & 74 & 248 & 52 & 277 & 75 \\
\hline R2 & 0.146 & 0.85 & 0.162 & 0.606 & 0.571 & 0.907 & 0.423 & 0.823 \\
\hline $\mathrm{F}$ & 0.939 & 5.937 & 1.422 & 3.338 & 7.322 & 17.957 & 5.396 & 10.955 \\
\hline Prob $>F$ & 0.5759 & 0.00 & 0.072 & 0.0002 & 0.00 & 0.00 & 0.00 & 0.00 \\
\hline \multicolumn{3}{|l|}{${ }^{*} \mathrm{p}<0.05$} & \multicolumn{2}{|c|}{$* * \mathrm{p}<0.01$} & & \multicolumn{2}{|c|}{$* * * \mathrm{P}<0.001$} & \\
\hline
\end{tabular}

The findings from the mining ores sector show that trade liberalization improves the ratio of ore exports to total export bilateral trade for the trading partners. Improvements in this ratio indicate that ore exports improved, thus signifying enhanced competitiveness. Under trade liberalization the results show that 27 of the 31 trading partners are significant, whereas in sub-sample 2005-2013, when the trade liberalization variable is not significant, this number drops drastically. This means trade liberalization does encourage extensive margins.

Table 5: Results of Machinery Industry

\begin{tabular}{|c|c|c|c|c|c|c|c|c|}
\hline \multirow[t]{2}{*}{ sample } & \multicolumn{2}{|c|}{ Imports 1996-2004 } & \multicolumn{2}{|c|}{ Imports 2005-2013 } & \multirow{2}{*}{$\begin{array}{l}\text { Exports } \\
\text { 2004 } \\
\text { Model } 1 \\
\end{array}$} & \multirow{2}{*}{$\begin{array}{r}\text { 1996- } \\
\text { Model } 2 \\
\end{array}$} & \multirow{2}{*}{$\begin{array}{l}\text { Exports } \\
2013 \\
\text { Model 1 } \\
\end{array}$} & \multirow{2}{*}{$\begin{array}{r}2005- \\
\text { Model } 2 \\
\end{array}$} \\
\hline & Model 1 & Model 2 & Model 1 & Model 2 & & & & \\
\hline Log income & 0.007 & -0.456 & -0.055 & -0.762 & $0.088^{* *}$ & $0.534^{* *}$ & $-0.073^{* *}$ & $-0.353^{* *}$ \\
\hline $\begin{array}{l}\text { Log } \\
\text { population }\end{array}$ & -0.094 & 1.191 & 0.036 & 3.78 & $-0.261^{*}$ & $-1.577^{*}$ & $0.29 *$ & 1.057 \\
\hline Log distance & 0.75 & -1.821 & -0.091 & -6.668 & $1.324^{*}$ & 2.114 & $-0.552^{* *}$ & $-2.522^{* *}$ \\
\hline development & 0.296 & -3.1 & $-0.31^{* * *}$ & $-4.753^{* * *}$ & $0.862^{*}$ & & $-0.715^{*}$ & -2.696 \\
\hline $\begin{array}{l}\text { Border } \\
\text { dummy }\end{array}$ & 0.95 & -1.268 & $-0.658^{* *}$ & $-7.09 *$ & $2.808^{*}$ & & 0.085 & 0.74 \\
\hline $\begin{array}{l}\text { Integration } \\
\text { dummy }\end{array}$ & -0.057 & -0.233 & 0.073 & 1.015 & $0.065^{*}$ & 0.139 & 0.046 & $-1.299 *$ \\
\hline ECOWAS & 0.102 & $-5.309 * * *$ & $-0.478^{* * *}$ & 2.085 & $0.599^{* * *}$ & -1.736 & -0.003 & 0.824 \\
\hline EAC & 0.07 & 0.342 & $-0.616^{* * *}$ & 0.513 & $0.121^{* *}$ & 0.385 & 0.014 & 0.264 \\
\hline Nafta & & & -0.165 & 3.035 & & $-3.96^{*}$ & & 0.025 \\
\hline EU & -0.012 & -0.745 & -0.364 & 2.644 & $\begin{array}{l}- \\
0.401^{* * *}\end{array}$ & $-4.767^{*}$ & $0.368^{*}$ & 0.761 \\
\hline $\begin{array}{l}\text { Exchange } \\
\text { rate }\end{array}$ & -0.0006 & 0.0004 & 0.001 & 0.043 & -0.001 & $-0.012^{*}$ & $0.003^{*}$ & 0.003 \\
\hline tariff & 0.007 & 0.125 & -0.008 & -0.151 & -0.003 & 0.003 & -0.003 & 0.032 \\
\hline $\begin{array}{l}\text { Tariff } \\
\text { liberalis } \\
\text { dummy }\end{array}$ & $-0.061^{* *}$ & -0.345 & 0.009 & 0.211 & -0.015 & -0.098 & 0.002 & 0.042 \\
\hline $\begin{array}{l}\text { Interaction } \\
\text { dummy }\end{array}$ & $9.1 \mathrm{e}-12$ & $3.4 \mathrm{e}-11$ & $2.1 \mathrm{e}-12$ & $1.2 \mathrm{e}-11$ & $8.9 \mathrm{e}-12$ & $4.3 \mathrm{e}-11$ & $\begin{array}{l}6.8 \mathrm{e}- \\
12^{* * *}\end{array}$ & $8.5 e-12$ \\
\hline constant & -3.806 & -3.210 & 3.04 & -41.253 & $-7.444^{* *}$ & 12.261 & -1.305 & 2.929 \\
\hline Country 2 & & & $-0.598^{* * *}$ & $-3.899 * *$ & $1.124^{*}$ & $-1.646^{*}$ & & $0.712^{* *}$ \\
\hline Country 3 & & & & & $-0.784^{*}$ & & $-0.317^{* *}$ & $-1.581^{* *}$ \\
\hline Country 4 & & & & & & $-1.781 *$ & $0.489 * * *$ & $1.292^{*}$ \\
\hline Country 5 & & & & & $0.515^{*}$ & & & \\
\hline Country 7 & & & & & - & - & $0.495^{*}$ & \\
\hline Country 8 & & & & & $\begin{array}{l}0.393^{* * *} \\
0.631^{* * *}\end{array}$ & $\begin{array}{l}1.676^{* * *} \\
2.825^{* * *}\end{array}$ & & \\
\hline Country 9 & & $-2.938^{* * *}$ & $-0.568 * * *$ & & $0.967^{* *}$ & & & $\begin{array}{l}- \\
1.529^{* * *}\end{array}$ \\
\hline Country 10 & & & & & $0.854^{* *}$ & & & \\
\hline Country 11 & & & & & & $-6.607^{*}$ & & \\
\hline Country 12 & & & & & $0.768^{* *}$ & & & \\
\hline
\end{tabular}




\begin{tabular}{|c|c|c|c|c|c|c|c|c|}
\hline \multicolumn{9}{|c|}{$\begin{array}{c}\text { Journal of Economics and Behavioral Studies (ISSN: 2220-6140) } \\
\text { Vol. 10, No. 5, pp. 125-137, October } 2018\end{array}$} \\
\hline Country 13 & & & & & & & $0.536^{* *}$ & \\
\hline Country 14 & & & $-0.261 *$ & $-3.97^{*}$ & & & $-0.33^{* * *}$ & $-\overline{1.748^{* * *}}$ \\
\hline $\begin{array}{l}\text { Country } 15 \\
\text { Country } 16\end{array}$ & & & $0.125^{*}$ & & $\begin{array}{l}0.962^{* *} \\
104^{*}\end{array}$ & $\begin{array}{l}0.761^{*} \\
-4.695^{*}\end{array}$ & & \\
\hline Country 18 & & & & & & & $-\overline{0.721^{* * *}}$ & $-\overline{3.784^{* * *}}$ \\
\hline $\begin{array}{l}\text { Country } 19 \\
\text { Country } 20 \\
\text { Country } 21\end{array}$ & & $-3.825^{* * *}$ & $-0.744^{* * *}$ & $-4.557^{* * *}$ & $\begin{array}{l}1.658^{*} \\
-0.386^{* *} \\
-1.54^{*}\end{array}$ & $-4.962^{* *}$ & $-0.134^{* *}$ & $-0.529 *$ \\
\hline $\begin{array}{l}\text { Country } 23 \\
\text { Country } 24 \\
\text { Country } 25\end{array}$ & & & & & $\begin{array}{l}-0.341^{* *} \\
0.806^{* *}\end{array}$ & $-3.206^{*}$ & $0.446^{*}$ & \\
\hline Country 26 & & & & & $-0.552^{*}$ & & $-\overline{0.361^{* * *}}$ & - \\
\hline $\begin{array}{l}\text { Country } 27 \\
\text { Country } 28 \\
\text { Country } 30\end{array}$ & & $-1.997^{* * *}$ & & & $\begin{array}{l}1.227^{*} \\
0.513^{*} \\
1.739^{*}\end{array}$ & & & \\
\hline Country 31 & & & & $3.349 *$ & & & & $-2.276^{*}$ \\
\hline $\mathrm{N}$ & 247 & 238 & 277 & 272 & 248 & 215 & 277 & 257 \\
\hline $\mathrm{R} 2$ & 0.439 & 0.629 & 0.777 & 0.676 & 0.767 & 0.615 & 0.81 & 0.821 \\
\hline $\mathrm{F}$ & 4.28 & 8.895 & 23.242 & 13.658 & 18.08 & 8.454 & 28.429 & 27.947 \\
\hline $\begin{array}{l}\text { Prob }>F \\
* \mathrm{p}<0.05\end{array}$ & 0.00 & 0.00 & $\begin{array}{l}0.00 \\
* * \mathrm{p}<0.01\end{array}$ & 0.00 & 0.00 & $\begin{array}{l}0.00 \\
* * * \mathrm{P}<0.00\end{array}$ & 0.00 & 0.00 \\
\hline
\end{tabular}

With regards to machinery, a closer examination of imports reveals that trade liberalization reduced the ratio of imports to total bilateral trade. This means that the rate of change is faster for bilateral trade when compared to imports for trading partners. Trade liberalization hinders extensive margins, indicating greater competition in sub-sample 2005-2013, where the assumption of monopolistic competition is also supported.

Table 6: Results of the Transport Industry

\begin{tabular}{|c|c|c|c|c|c|c|c|c|}
\hline \multirow[t]{2}{*}{ sample } & \multicolumn{2}{|c|}{ Imports 1996-2004 } & \multicolumn{2}{|c|}{ Imports 2005-2013 } & \multirow{2}{*}{$\begin{array}{l}\text { Exports } \\
2004 \\
\text { Model } \\
1\end{array}$} & \multirow{2}{*}{$\begin{array}{r}\text { 1996- } \\
\text { Model } 2\end{array}$} & \multirow{2}{*}{$\begin{array}{l}\text { Exports } \\
2013 \\
\text { Model } 1\end{array}$} & \multirow{2}{*}{$\begin{array}{r}2005 \\
\text { Model 2 }\end{array}$} \\
\hline & Model 1 & Model 2 & Model 1 & Model 2 & & & & \\
\hline Log income & 0.053 & -0.505 & 0.022 & -0.197 & 0.014 & -0.203 & 0.012 & $1.131^{* *}$ \\
\hline $\begin{array}{l}\text { Log } \\
\text { population }\end{array}$ & -0.265 & 0.160 & -0.051 & -0.203 & -0.123 & -1.365 & 0.008 & $-3.918^{*}$ \\
\hline Log distance & 1.294 & 1.86 & 0.086 & 2.497 & 0.576 & 1.029 & 0.246 & 3.709 \\
\hline development & 0.586 & -3.472 & 0.084 & -2.037 & 0.262 & -3.001 & -0.093 & $4.646^{* * *}$ \\
\hline $\begin{array}{l}\text { Border } \\
\text { dummy }\end{array}$ & 1.479 & 3.94 & -0.063 & -0.96 & 1.149 & & 0.072 & $-5.165^{*}$ \\
\hline $\begin{array}{l}\text { Integration } \\
\text { dummy }\end{array}$ & $0.118^{*}$ & 0.925 & 0.043 & 1.456 & 0.003 & 0.119 & $0.631^{* * *}$ & -0.137 \\
\hline ECOWAS & 0.298 & -1.861 & 0.016 & -2.26 & 0.126 & -0.775 & $0.49^{* * *}$ & -2.933 \\
\hline EAC & 0.1 & 0.462 & 0.01 & -1.195 & -0.011 & -0.323 & $-0.124^{*}$ & $2.492^{* *}$ \\
\hline Nafta & & & 0.108 & -0.764 & & & & 1.789 \\
\hline EU & -0.125 & 2.055 & -0.024 & -1.773 & $0.22^{*}$ & 1.294 & $0.338^{*}$ & -1.58 \\
\hline $\begin{array}{l}\text { Exchange } \\
\text { rate }\end{array}$ & 0.001 & 0.023 & -0.0005 & -0.001 & -0.0007 & -0.018 & 0.0007 & -0.016 \\
\hline tariff & $-0.037^{*}$ & -0.209 & 0.016 & -0.3 & $\begin{array}{l}- \\
0.017^{* *}\end{array}$ & $-0.392^{*}$ & -0.023 & -0.1007 \\
\hline
\end{tabular}




\begin{tabular}{|c|c|c|c|c|c|c|c|c|}
\hline \multicolumn{9}{|c|}{$\begin{array}{l}\text { Journal of Economics and Behavioral Studies (ISSN: 2220-6140) } \\
\text { Vol. 10, No. 5, pp. 125-137, October } 2018 \\
\end{array}$} \\
\hline $\begin{array}{l}\text { Tariff } \\
\text { liberalis } \\
\text { dummy }\end{array}$ & $0.048^{*}$ & -0.062 & -0.012 & -0.33 & 0.0003 & $-0.435^{*}$ & 0.001 & -0.08 \\
\hline $\begin{array}{l}\text { Interaction } \\
\text { dummy }\end{array}$ & $-6.7 e-13$ & $1.8 \mathrm{e}-11$ & $1.0 \mathrm{e}-12$ & $1.9 \mathrm{e}-11$ & $\begin{array}{l}2.1 \mathrm{e}- \\
11^{* *}\end{array}$ & $4.7 \mathrm{e}-10^{*}$ & $\begin{array}{l}8.1 \mathrm{e}- \\
12^{* * *}\end{array}$ & $7.7 \mathrm{e}-11^{*}$ \\
\hline $\begin{array}{l}\text { constant } \\
\text { Country } 2 \\
\text { Country } 3\end{array}$ & -5.225 & 1.63 & -0.184 & -4.5 & -1.529 & 52.882 & -3.165 & \\
\hline $\begin{array}{l}\text { Country } 4 \\
\text { Country } 5 \\
\text { Country } 7 \\
\text { Country } 8\end{array}$ & $0.3901^{*}$ & & & & & & & \\
\hline Country 9 & & & & & & & $0.558^{* * *}$ & $4.186^{* * *}$ \\
\hline Country 10 & & & $0.095^{* * *}$ & & & & $-\overline{0.827^{* * *}}$ & $1.305^{* *}$ \\
\hline Country 11 & & & & & & & & \\
\hline Country 12 & & & $0.282^{* * *}$ & & & & $-\overline{0.886^{* * *}}$ & $1.075^{*}$ \\
\hline Country 13 & & & & & & & & $1.412^{* *}$ \\
\hline Country 14 & & & $0.161^{*}$ & & & & & $4.09^{* * *}$ \\
\hline Country 15 & & & & & & & $-\overline{-} 911^{* * *}$ & \\
\hline $\begin{array}{l}\text { Country } 16 \\
\text { Country } 17 \\
\text { Country } 18\end{array}$ & $0.2306^{*}$ & & & & & & $0.592^{* * *}$ & \\
\hline $\begin{array}{l}\text { Country } 19 \\
\text { Country } 20\end{array}$ & & & $0.082^{* *}$ & & & & & $1.76^{* *}$ \\
\hline Country 21 & & & & & & & & $8.9^{*}$ \\
\hline $\begin{array}{l}\text { Country } 23 \\
\text { Country } 24\end{array}$ & & & & & & & & $6.833^{*}$ \\
\hline Country 25 & & & $0.249^{* * *}$ & & & & $-\overline{0.888^{* * *}}$ & \\
\hline $\begin{array}{l}\text { Country } 26 \\
\text { Country } 27\end{array}$ & & & & & & & $0.194 *$ & \\
\hline Country 28 & & & $0.11^{* * *}$ & & & & $-\overline{0.924 * * *}$ & \\
\hline $\begin{array}{l}\text { Country } 30 \\
\text { Country } 31\end{array}$ & & & & & & & & $7.45^{*}$ \\
\hline $\mathrm{N}$ & 247 & 224 & 277 & 261 & 248 & 214 & 277 & 257 \\
\hline R2 & 0.49 & 0.718 & 0.86 & 0.657 & 0.712 & 0.716 & 0.868 & 0.737 \\
\hline $\mathrm{F}$ & 5.267 & 12.783 & 41.03 & 11.93 & 13.591 & 13.3 & 43.77 & 17.081 \\
\hline $\begin{array}{l}\text { Prob }>F \\
* \mathrm{p}<0.05\end{array}$ & 0.00 & 0.00 & $\begin{array}{l}0.00 \\
* * \mathrm{p}<0.01\end{array}$ & 0.00 & 0.00 & $\begin{array}{l}0.00 \\
* * * \mathrm{P}<0.00\end{array}$ & 0.00 & 0.00 \\
\hline
\end{tabular}

An inspection of the transport manufacturing industry unveils that under trade liberalization, the ratio of imports to bilateral trade increases, meaning a rise in imports, when compared to a situation with no trade liberalization. The growth in imports shows a shift from the domestic market to the international market. Additionally, there are less significant trading partners in sub-sample 1996-2004 than 2005-2013. With exports, the trade liberalization variable reduced the elasticity of trade flows, thus limiting the impact of changes in policy aimed at improving trade flows.

\section{Conclusion and Recommendations}

The analysis reveals that the heterogeneity of industries examined results in different impact levels of trade liberalization on trade patterns. The tariff liberalization variable lowers the responsiveness of trade flows to 
policy changes in other determinants of the gravity model. This means that any policy action linked to other determinants tends to have a reduced influence on trade flows. This phenomenon is accompanied by a situation whereby tariff liberalization encourages less competition among trading partners as the number of significant trading partners is lower when trade liberalization is significant, creating a stronger case for consolidation within international markets. This is substantiated by the findings who noted that huge demand elasticity increased the sensitivity of intensive margins. This may be attributed to the lack of improvement in terms of productivity, as a result of slow levels of innovation. It is also noted that trade liberalization can improve on extensive margins, but only in a few industries, and where there is also less evidence of improvement. Having analyzed the effect of trade liberalization on industry performance and on trade patterns, the study concludes that South Africa has not benefitted as much as expected. Some industries have fared better than others, but the general view based on results obtained is that trade liberalization has a limited effect on enhancing trade patterns. Various crises that have affected the Eurozone and individual European countries have contributed to the decline in exports to this area. On average, other regional blocs have seen a substantial rise in export values from South Africa to their economies since 2008.

Recommendations: Tariff liberalization lowers the responsiveness of trade flows to policy change in other determinants of the gravity model. This makes it difficult to influence trade flows. The ability of domestic industries to tap into International practices needs to be vastly improved as these stem the results of innovation. Research and development is vital for domestic industries in the international market; hence, policy aimed at improving the ability of domestic industries productivity levels, will amplify the positive effects of trade liberalization on both extensive and intensive margins. Consideration should be given to focusing on price elastic products, thus resulting in in a structural shift domestically.

\section{References}

Adenikinju, A. \& Chete, L. (2002). Productivity, market structure and Trade liberalization in Nigeria. AERC Research paper, 126.

Anderson, J. E. \& Wincoop, E. (2003). Gravity with gravitas: A solution to the border puzzle. The American Economic Review, 93, 170-192.

Appleyard, D., Field, A. \& Cobb, S. (2008). International Economics. New York: McGraw-Hill.

Black, A. (2001). Globalization and restructuring in the South African automotive industry. Journal of International Development, 13, 779-769.

Buono, I. \& Lalanne, G. (2012). The effect of the Uruguay round on the intensive and extensive margins of trade. Journal of International Economics, Elsevier, 86 269-283.

Chen, W. (2013). The extensive and Intensive margin of exports: The role of innovation. The World Economy, 36(5), 607-635.

Debaere, P. \& Mostashari, S. (2010). Do tariffs matter for the extensive margin of international trade: An empirical analysis. Journal of International Economics, 81, 163-169.

Fedderke, J. \& Vaze, P. (2001). The nature of South Africa's trade patterns by economic sector and the extent of trade liberalization during the course of the 1990's. The South African Journal of Economics, 69.

Feenstra, R. \& Taylor, A. (2014). International Economics, 3rd edition. New York Worth Publishers.

Fiestas, I. (2005). The effects of trade liberalization on growth, poverty and inequality. CILAE, nota tecnica.

Kanda, P. T. \& Jordaan, A. C. (2010). Trade diversion and Trade creation: Augmented Gravity model study for South Africa. Trade \& industrial policy strategies paper series 2010.

Krugman, P. (1980). Scale Economies, Product Differentiation, and the Pattern of Trade. The American Economic Review, 70, 950-959.

Melitz, M. J. (2003). The impact of trade on intra-industry reallocations and aggregate industry productivity. Econometrica, 71, 1695-1725.

Stiglitz, J. (2002). Globalization and its Discontents. New York: Penguin group.

Twerefu, D. K. (2009). Mineral Exploitation, Environmental sustainability and sustainable development in EAC, SADC and ECOWAS regions. African trade policy centre, work in progress, 79.

Van der Westhuizen, C. (2006). Trade and poverty: A case study of SA clothing industry, Trade and poverty project, SALDRU, University of Cape Town. 